ISSN 0258-7122 (Print), 2408-8293 (Online)

Bangladesh J. Agril. Res. 42(4): 749-755, December 2017

\title{
INTERCROPPING OF BANANA WITH POTATO AND VEGETABLES
}

\author{
T. HASAN ${ }^{1}$, M. Z. H. PRODHAN ${ }^{2}$, A. ISLAM ${ }^{3}$ AND M. A. AKTHER ${ }^{4}$
}

\begin{abstract}
An intercrop-based experiment was conducted for two consecutive years during September 2012 to October 2014 at farmer's field of MLT site, Shibganj, Bogra to find out the performance of banana intercropped with potato and vegetables. There were three intercrop-based treatments i.e. Banana + Potato, Banana + Radish + Potato and Banana + Cauliflower + Potato were tested along with Sole Banana. The results revealed that all the intercrops produced higher banana equivalent yield over the sole banana in both the years. However, among the intercrop combinations, Banana + Cauliflower + Potato provided the highest equivalent yield (104.04 tha ${ }^{-1}$ in 2012-13 and 122.50 tha ${ }^{-1}$ in 2013-14) followed by Banana + Radish + potato. Sole banana produced the lowest equivalent yield in both the cropping seasons. Higher gross margin was also obtained from the intercrop combinations. Among the intercrops, Banana + cauliflower + Potato provided higher gross margin (Tk.656898 ha-1) but due to higher cost, this treatment failed to show higher BCR than Banana + Radish + Potato.
\end{abstract}

Keyword: Intercrop, banana equivalent yield, potato, radish, cauliflower.

\section{Introduction}

Banana (Musa sapientum L.) is one of the popular and major fruits in Bangladesh in respect of acreage and production. It is one of the cheapest, most plentiful and nourishing of all fruits which is available throughout the year. It ranks top position among the major fruit crops grown in the country, which comprises about $42 \%$ of the total fruit production. Banana is largely grown in well drained high land, which is also suitable for growing other cash crops. The inter row space of Banana remains under utilized in the early growing period. During this period, short duration crops may be grown as intercrops with Banana (Bose, 1990). Intercropping with banana is more profitable without much investment (Haque, 1984). The success of intercropping systems depends mostly on selection of component crops as well as agronomic modification of resources used (Midnare, 1993). Selection of intercrops should be done in such a way that, they have no or little adverse effect on the main crop. Therefore, this experiment has been undertaken to optimize the productivity and economic return of Banana based intercropping system.

\section{Materials and methods}

The intercrop-based experiment carried out for the two consecutive years during September 2012 to October 2014 at farmer's field of the MLT site, Shibganj in

\footnotetext{
${ }^{1 \& 4}$ On-Farm Research Division, Bangladesh Agricultural Research Institute (BARI), Bogra, ${ }^{2}$ On-Farm Research Division, BARI, Kushtia, ${ }^{3}$ On-Farm Research Division, BARI, Gaibandha, Bangladesh.
} 
the medium highland under AEZ-3. The trial laid out in Randomized Complete Block (RCB) design with six dispersed replications. The treatments were- $\mathrm{T}_{1}$ : Sole Banana, $\mathrm{T}_{2}$ : Banana + Potato, $\mathrm{T}_{3}$ : Banana + Radish + Potato and $\mathrm{T}_{4}$ : Banana + Cauliflower + Potato. The fertilizers used @ 277-96-300-90-5-1.5 kg ha-1 NPKSZnB and Cowdung $15 \mathrm{t} \mathrm{ha}^{-1}$. $\mathrm{N}$ was applied in three equal splits at 20,60 and 90 days after planting (DAP). The entire quantity of $\mathrm{P}, \mathrm{K}, \mathrm{S}, \mathrm{Zn}, \mathrm{B}$ and Cowdung applied during pit preparation at 4 to 5 days prior to planting.

Table 1. Crop management practices adopted for different crops in field experiments

\begin{tabular}{|c|c|c|c|c|}
\hline $\begin{array}{c}\text { Crops and their } \\
\text { management }\end{array}$ & Banana & Radish & Cauliflower & Potato \\
\hline Varity & Rangin maher sagar & Roki & Thirty-three & Granola \\
\hline Date of sowing & $\begin{array}{c}15 \text { Sept. } 2012 \\
\text { and } \\
10 \text { Oct. } 2013\end{array}$ & $\begin{array}{c}20 \text { Sept. } 2012 \\
\text { and } \\
12 \text { Oct. } 2013\end{array}$ & $\begin{array}{l}20 \text { Sept. } 2012 \\
\text { and } \\
12 \text { Oct. } 2012\end{array}$ & $\begin{array}{l}\text { 06 Nov. } 2012 \\
\text { and } \\
\text { 02 Dec. } 2013\end{array}$ \\
\hline $\begin{array}{l}\text { Planting } \\
\text { materials }\end{array}$ & Sucker & Seed & Seedling & Tuber \\
\hline Spacing & $1 \mathrm{~m} \times 1.25 \mathrm{~m}$ & $\begin{array}{l}45 \mathrm{~cm} \text { line } \\
\text { sowing }\end{array}$ & $60 \times 45 \mathrm{~cm}$ & $45 \times 15 \mathrm{~cm}$ \\
\hline $\begin{array}{l}\text { Fertilizer as } \\
\text { basal } \\
\text { (NPKSZnB+15 } \\
\text { t/ha CD) }\end{array}$ & $\begin{array}{c}277-96-300-90-5- \\
1.5\end{array}$ & $64-25-51-0-0-0$ & $60-15-45-0-0-0$ & $20-12-50-15-0-0$ \\
\hline Pesticides used & $\begin{array}{l}\text { Imitaf for banana } \\
\text { leaf and fruit beetle } \\
\text { (1 times) }\end{array}$ & $\begin{array}{l}\text { Carate for flee } \\
\text { beetle ( } 2 \text { times) }\end{array}$ & $\begin{array}{l}\text { Cythrine for } \\
\text { aphid (1 times) }\end{array}$ & $\begin{array}{l}\text { Dithane M-45 } \\
\text { for Late blight } \\
\text { (2 times) }\end{array}$ \\
\hline Irrigation & $\begin{array}{l}1^{\text {st }} \text { irrigation during } \\
\text { sucker plantation } \\
\text { and rest irrigations } \\
\text { were done in } \\
\text { intercrops }\end{array}$ & $\begin{array}{l}1^{\text {st }} \text { and } 2^{\text {nd }} \\
\text { Irrigation at } \\
\text { germination } \\
\text { and root } \\
\text { development } \\
\text { stage }\end{array}$ & $\begin{array}{l}1^{\text {st }} 2^{\text {nd }} \text { and } 3^{\text {rd }} \\
\text { Irrigation at } \\
\text { seedling, } \\
\text { vegetative and } \\
\text { head initiation } \\
\text { stage }\end{array}$ & $\begin{array}{c}1^{\text {st }} 2^{\text {nd }} \text { and } 3^{\text {rd }} \\
\text { Irrigation at } \\
\text { vegetative, } \\
\text { stolon formation } \\
\text { and tuber } \\
\text { development } \\
\text { stage }\end{array}$ \\
\hline Weeding & $\begin{array}{l}2 \text { times (vegetative } \\
\text { and fruiting stage) }\end{array}$ & $\begin{array}{c}2 \text { times } \\
\text { (vegetative and } \\
\text { root } \\
\text { development } \\
\text { stage) }\end{array}$ & $\begin{array}{l}2 \text { times } \\
\text { (vegetative and } \\
\text { prior to fruiting } \\
\text { stage) }\end{array}$ & vegetative stage \\
\hline Date of harvest & $\begin{array}{l}20 \text { Oct. } 2013 \\
\text { and } \\
19 \text { Oct. } 2014\end{array}$ & $\begin{array}{l}11 \text { Nov. } 2012 \\
\text { and } \\
30 \text { Nov. } 2013\end{array}$ & $\begin{array}{l}22 \text { Nov. } 2012 \\
\text { and } \\
19 \text { Dec. } 2013\end{array}$ & $\begin{array}{l}16 \text { Jan. } 2013 \\
\text { and } \\
15 \text { Feb. } 2014\end{array}$ \\
\hline
\end{tabular}

The gross economic return was calculated on the basis of prevailing market price of the products. All the data were statistically analyzed and the mean comparisons were made by LSD at 5\% level (Gomez and Gomez, 1984). 
Thirty to forty days aged suckers were transplanted on 20 September. Radish and cauliflower were sown at five days after planting of banana. First weeding was done at 15 days after radish and cauliflower sowing/transplanting while the banana was 20 days old after planting. Second weeding was done at 40 DAS especially during root development stage of radish as well as prior to head initiation of cauliflower. Potato tubers were planted after harvest of radish and cauliflower as intercrop with banana. Weeding followed by earthing up was done at 25 days after planting of potato. Irrigation was done for banana 10 days (radish and cauliflower at 5 DAS) and 25 days (radish and cauliflower at 20 DAS) after sucker planting. The $3^{\text {rd }}$ irrigation for cauliflower was done at 40 DAS (before head initiation) while the banana plant was 45 days old. Potato was irrigated at 25, 50 and 65 days after planting (age of banana plant was 81, 106 and 121 DAS respectively). Karate (Lambda-Cyhalothrin) 25EC @ 1ml/L of water was sprayed at 5 and 12 days after germination (DAG) to control flea beetle of Radish. Cythrine (Cypemethrine) @ 1ml/L of water was sprayed at 15 days after germination (DAG) to control aphid of Cauliflower. Dithane M-45 @2g/L was sprayed at 45 and 55 days after sowing to control late blight of potato. Imitaf (Imidachloprid) @ $0.5 \mathrm{ml} / \mathrm{L}$ was sprayed at fruiting stage of banana to control banana leaf and fruit beetle. Banana equivalent yield and production efficiency was calculated.

\section{Results and Discussion}

\section{Yield contributing characters of banana:}

The results presented in Table 2 indicated that yield contributing characters of banana were not varied significantly among the treatments in both the years. It was noticed that there was no significant adverse effect of the intercrops on the performances of banana regarding yield and yield contributing characters. This probably due to the advantages came from root and canopy structures of the main crop banana and all intercrops grown at early stages of planting.

\section{Yield of banana and component crops:}

Slightly higher yield was observed from the sole banana cultivation. Banana grown in association with intercrops like potato, radish and cauliflower contributed to slightly lower yield (9-12\%). This might be due to the competition by the intercrops for the same resources i.e. space, nutrition, water etc grown in association with banana. However, banana yield ranged from 55.66 to 62.49 tha $^{-1}$ in 2012-13 and 51.25 to 57.5 tha $^{-1}$ in 2013-14. Radish and cauliflower yield was recorded as 33.88 to 33.18 tha $^{-1}$ and 30.59 to 38.48 tha $^{-1}$ in the corresponding years 2012-13 and 2013-14. However, tuber yield was far below the potential yield of potato but it contributed to the higher system productivity with the same management practices. Similar observation was noticed by Rahman et al. (2006). Potato yield ranged from 8.54 to 12.64 tha $^{-1}$ and 10.82 to 12.02 tha $^{-1}$ in 2012-13 
and 2013-14 respectively. It was observed that potato grown after radish and cauliflower produced slightly lower tuber yield than that of potato and banana grown only. The reason might be that, the preceding intercrops radish and cauliflower delayed the optimum sowing time for potato cultivation. Therefore, growing potato after radish and cauliflower as intercrop with banana might be involved in comparatively lower tuber yield as well as acted as a risk factor for exposing diseases to the next crop potato. When two crops (Banana + Potato) grown showed 9\% yield reduction while three crops (Banana + Radish/Cauliflower + Potato) resulted in 9-12\% reduction than sole banana.

Table 2. Yield contributing characters of banana under intercropping system at Shibganj, Bogra during 2012-13 and 2013-14.

\begin{tabular}{|c|c|c|c|c|c|c|c|c|c|c|}
\hline \multirow{2}{*}{$\begin{array}{l}\text { Treatment } \\
\text { combination }\end{array}$} & \multicolumn{2}{|c|}{$\begin{array}{l}\text { Length of } \\
\text { hands }(\mathrm{cm})\end{array}$} & \multicolumn{2}{|c|}{$\begin{array}{l}\text { No. of hands/ } \\
\text { bunch }\end{array}$} & \multicolumn{2}{|c|}{$\begin{array}{c}\text { No. of finger } \\
\text { /hands }\end{array}$} & \multicolumn{2}{|c|}{$\begin{array}{l}\text { Wt. of hands } \\
(\mathrm{Kg})\end{array}$} & \multicolumn{2}{|c|}{$\begin{array}{l}\text { Wt. of bunch } \\
(\mathrm{Kg})\end{array}$} \\
\hline & $\begin{array}{c}2012- \\
13\end{array}$ & $\begin{array}{c}2013- \\
14\end{array}$ & $\begin{array}{c}2012- \\
13\end{array}$ & $\begin{array}{c}2013- \\
14\end{array}$ & $\begin{array}{c}2012- \\
13\end{array}$ & $\begin{array}{c}2013- \\
14\end{array}$ & \begin{tabular}{|c|}
$2012-$ \\
13
\end{tabular} & $\begin{array}{c}2013- \\
14\end{array}$ & $\begin{array}{c}2012- \\
13\end{array}$ & $\begin{array}{c}2013- \\
14\end{array}$ \\
\hline $\begin{array}{l}\mathrm{T}_{1} \text { : Sole } \\
\text { Banana }\end{array}$ & 91.03 & 90.68 & 9.00 & 10.00 & 17.00 & 16.00 & 2.72 & 2.74 & 25.00 & 23.41 \\
\hline $\begin{array}{l}\mathrm{T}_{2} \text { : Banana + } \\
\text { Potato }\end{array}$ & 88.91 & 87.37 & 9.00 & 9.00 & 15.00 & 15.00 & 2.51 & 2.43 & 22.66 & 21.91 \\
\hline $\begin{array}{l}\mathrm{T}_{3} \text { : Banana } \\
\text { +Radish + } \\
\text { Potato }\end{array}$ & 89.21 & 88.24 & 9.00 & 9.00 & 15.00 & 15.00 & 2.54 & 2.48 & 22.83 & 21.00 \\
\hline $\begin{array}{l}\mathrm{T}_{4} \text { : Banana + } \\
\text { Cauliflower + } \\
\text { Potato }\end{array}$ & 88.80 & 88.17 & 9.00 & 9.00 & 16.00 & 15.00 & 2.51 & 2.15 & 22.66 & 20.50 \\
\hline LSD (0.05) & NS & NS & NS & NS & NS & NS & NS & NS & NS & NS \\
\hline $\mathrm{CV}(\%)$ & 3.18 & 4.16 & 3.57 & 9.80 & 9.56 & 8.28 & 5.01 & 8.57 & 9.26 & 9.12 \\
\hline
\end{tabular}

\section{System productivity:}

System productivity was measured in terms of banana equivalent yield from different treatment combinations (Table 4). Though the yield of banana was not differed remarkably but component crops yield played a significant role for increasing system productivity in terms of banana equivalent yield. Yield of intercrops i.e. radish, cauliflower as well as potato contributed to higher system productivity over the only banana cultivation. In case of banana equivalent yield, all the intercropping treatments showed better performance than sole crop cultivation. The highest equivalent yield $\left(104.04\right.$ tha $\left.^{-1}\right)$ was obtained from the treatment $\mathrm{T}_{4}$ (Banana + Cauliflower + Potato) which was statistically similar with $\mathrm{T}_{3}$ (Banana + Radish + Potato) but differed from other treatments. The lowest yield (62.49 tha $\left.^{-1}\right)$ was obtained from sole banana. In 2011-12, the highest equivalent yield $(122.50 \mathrm{t} / \mathrm{ha})$ was obtained from the treatment $\mathrm{T}_{4}$ which was 
statistically similar with $\mathrm{T}_{3}$ but differed from other treatments. The lowest system equivalent yield (59.49 tha $^{-1}$ ) was obtained from sole banana which was statistically similar with $\mathrm{T}_{2}\left(71.14\right.$ tha $\left.^{-1}\right)$. Higher productivity from the intercrop combinations indicated the consequences of higher production from the component crops under intensified land use systems. Musa et al. (2013) reported the higher system productivity from the intercrop based systems over the sole crop. Nazrul et al. (2007) also showed higher system productivity in Banana intercrop with vegetables combinations than sole banana.

Table 3. Yield of banana and component crops at Shibganj, Bogra during 2012-13 and 2013-14.

\begin{tabular}{|c|c|c|c|c|c|c|c|c|}
\hline \multirow{2}{*}{$\begin{array}{l}\text { Treatment } \\
\text { combination }\end{array}$} & \multicolumn{2}{|c|}{$\begin{array}{l}\text { Fruit yield of } \\
\text { banana }\left(\text { tha }^{-1}\right)\end{array}$} & \multicolumn{2}{|c|}{$\begin{array}{l}\text { Tuber yield of } \\
\text { potato }\left(\text { tha }^{-1}\right)\end{array}$} & \multicolumn{2}{|c|}{$\begin{array}{c}\text { Yield of radish \& } \\
\text { cauliflower }\left(\text { tha }^{-1}\right)\end{array}$} & \multicolumn{2}{|c|}{ Crop index $(\%)^{*}$} \\
\hline & $\begin{array}{c}2012- \\
13\end{array}$ & $\begin{array}{c}2013- \\
14\end{array}$ & $\begin{array}{c}2012- \\
13\end{array}$ & $\begin{array}{c}2013- \\
14\end{array}$ & $2012-13$ & 2013-14 & 2012-13 & 2013-14 \\
\hline $\mathrm{T}_{1}$ : Sole Banana & 62.49 & 57.5 & - & - & - & - & 100.00 & 100.00 \\
\hline $\begin{array}{l}\mathrm{T}_{2} \text { : Banana + } \\
\text { Potato }\end{array}$ & 57.08 & 54.79 & 12.64 & 12.02 & - & - & 91.34 & 95.29 \\
\hline $\begin{array}{l}\mathrm{T}_{3} \text { : Banana } \\
+ \text { +Radish + } \\
\text { Potato }\end{array}$ & 56.66 & 52.08 & 10.97 & 11.25 & 33.88 & 33.18 & 90.67 & 90.57 \\
\hline $\begin{array}{l}\mathrm{T}_{4} \text { : Banana + } \\
\text { Cauliflower + } \\
\text { Potato }\end{array}$ & 55.13 & 51.25 & 8.54 & 10.82 & 30.59 & 38.48 & 88.22 & 89.13 \\
\hline LSD (0.05) & 7.83 & 6.95 & 1.72 & 1.17 & - & - & - & - \\
\hline $\mathrm{CV}(\%)$ & 7.83 & 10.48 & 12.49 & 8.03 & - & - & - & - \\
\hline
\end{tabular}

*Crop index $(\%)$ means percent reduction or increase of yield as compared to sole crop in intercrop situation.

\section{Production efficiency:}

Production efficiency was measured for the treatments and presented in the Table 4. Production efficiency was found always higher from intercrop combinations than that of sole crop cultivation (only banana). The intercrops based results supported the findings of Rahman et al. (2006) and Bantie (2015). The maximum production efficiency $(260.10 \mathrm{~kg} / \mathrm{ha} /$ day in $2012-13$ and 327.54 $\mathrm{kg} / \mathrm{ha} /$ day in 2013-14) was recorded from $\mathrm{T}_{4}$ (Banana + Cauliflower + Potato) followed by $\mathrm{T}_{3}$ (Banana + Radish + Potato) and the minimum (156.23 $\mathrm{kg} / \mathrm{ha} /$ day in $2012-13$ and $153.74 \mathrm{~kg} / \mathrm{ha} /$ day in 2013-14) from sole (Banana). Higher production efficiency from the intercropping systems indicated the suitability, productivity as well as profitability of the systems over the sole crop cultivation. 
Table 4. System productivity (banana equivalent yield) and production efficiency of banana at Shibganj, Bogra during 2012-13 and 2013-14

\begin{tabular}{|c|c|c|c|c|c|c|}
\hline \multirow{2}{*}{ Treatment } & \multicolumn{2}{|c|}{$\begin{array}{c}\text { Banana equivalent } \\
\text { yield }\left(\mathrm{tha}^{-1}\right)\end{array}$} & \multicolumn{2}{|c|}{$\begin{array}{l}\text { Production efficiency } \\
\qquad\left(\mathrm{kg}^{-1} \mathrm{ha}^{-1} \mathrm{day}^{-1}\right)\end{array}$} & \multicolumn{2}{|c|}{$\begin{array}{l}\text { Crop duration } \\
\text { (days) }\end{array}$} \\
\hline & $2012-13$ & 2013-14 & $2012-13$ & 2013-14 & $2012-13$ & 2013-14 \\
\hline $\mathrm{T}_{1}:$ Sole Banana & 62.49 & 57.50 & 156.23 & 153.74 & & \\
\hline $\mathrm{T}_{2}$ : Banana + Potato & 72.47 & 69.81 & 181.18 & 186.66 & & \\
\hline $\begin{array}{l}\mathrm{T}_{3} \text { : Banana +Radish } \\
+ \text { Potato }\end{array}$ & 96.21 & 107.62 & 240.53 & 287.75 & 400 & 374 \\
\hline $\begin{array}{l}\mathrm{T}_{4}: \quad \text { Banana }+ \\
\text { Cauliflower }+ \text { Potato }\end{array}$ & 104.04 & 122.50 & 260.10 & 327.54 & & \\
\hline $\operatorname{LSD}(0.05)$ & 9.21 & 13.46 & - & - & - & - \\
\hline $\mathrm{CV}(\%)$ & 10.59 & 12.24 & - & - & - & - \\
\hline
\end{tabular}

Table 5. Economic performance of banana with potato and vegetables in intercropping system (Av. of 2012-13 and 2013-14)

\begin{tabular}{l|c|c|c|c}
\hline \multicolumn{1}{c|}{ Treatment } & $\begin{array}{c}\text { Gross return } \\
\left(\mathrm{Tk} \mathrm{ha}^{-1}\right)\end{array}$ & $\begin{array}{c}\text { Total cost } \\
\left(\mathrm{Tk} \mathrm{ha}^{-1}\right)\end{array}$ & $\begin{array}{c}\text { Gross margin } \\
\left(\mathrm{Tk} \mathrm{ha}^{-1}\right)\end{array}$ & BCR \\
\hline $\mathrm{T}_{1}$ : Sole Banana & 479960 & 123550 & 356410 & 3.88 \\
$\mathrm{~T}_{2}$ : Banana + Potato & 569120 & 166252 & 402868 & 3.42 \\
$\mathrm{~T}_{3}$ : Banana +Radish + & 815320 & 192527 & 622793 & 4.23 \\
$\begin{array}{l}\text { Potato } \\
\mathrm{T}_{4} \text { : Banana }+\end{array}$ & 906160 & 249262 & 656898 & 3.63 \\
Cauliflower+ Potato & & & & \\
\hline
\end{tabular}

Price of output (Tk/kg): Banana @ Tk 8/kg, Radish @ Tk 6/kg (2012-13) and Tk 10/kg (2013-14), Potato @ Tk 10/kg and Cauliflower @ Tk 10/kg (2012-13) and Tk 12/kg (2013-14)

Input cost (Tk/kg): Urea @ 16, TSP @22, MoP @15, Gypsum @ 10, Zinc sulphate @180, Boric acid@400

\section{Cost and Return Analysis}

Considering the prevailing market price, cost and return analysis were presented in the Table 5. It was noticed that all the intercrop combinations resulted in higher gross return than that of sole banana produced. Similar statement regarding higher yield from intercropping system was given by Grimes et al. (1983) and Kurata (1986). Higher gross return (Tk. 906160 ha $^{-1}$ ) was achieved by intercropping of banana with cauliflower + potato followed by banana + radish + potato (Tk. $615320 \mathrm{ha}^{-1}$ ). Similar trend was followed in case of gross margin. If considered benefit cost ratio, intercrop potato with banana and potato + cauliflower with banana failed to show higher returns than sole banana as higher 
cost was involved. But only Banana + Radish + Potato showed higher BCR (4.23) than sole banana though reasonable cost was increased. So, cost of cultivation should be considered while growing intercrops with the main crop.

\section{Conclusion}

The result showed that Banana with radish and potato as intercropped combination gave higher economic return than sole and other combination. So, this combination could be advocated to Banana growing area of Shibganj, Bogra.

\section{References}

Bantie, Y. B. 2015. Determination of Effective Spatial Arrangement for Intercropping of Maize (Zea mays L.) and Potato (Solanum tuberosum L.) Using Competition Indices Ethiopia. J Horticulture 2: 137.

Bose, T.K. 1990. Fruits: Tropical and Sub-tropical (pp132-185). Calcutta, India: Naya Prokash.

Gomez, K.A and Gomez, A.A. 1984. Statistical procedures for Agricultural Research, Int. Rice Res. Inst. John Willy and Sons, New York, Chickester, Brisbane, Torento, Singapore, P. 643.

Grimes, A., A. M. Quasem, M. S. Uddin, N. Jahiruddin and R. N. Malik, 1983. Performance of Different Cropping Patterns in 1992-93 at the Cropping System Research Site, Hathazari, Chittagong, RARS, 1.

Haque. M.A. 1984. Intercropping of Banana and its economic return, Bangladesh J. Agril. 3:53- 55

Kurata, T. 1986. A Study on Farming System in USA. Quart. J. Agric. Ecol., 26:179-205.

Musa, M., A. K. Azad and T. R. Gurung (Eds.). 2013. Popularizing multiple cropping innovation as a means to raise crop productivity and farm income in SAARC countries.

Nazrul M. I., M. A. Rahman and M. A. Quayyum. 2007. Performance of intercropping Banana with vegetables. SAARC J. Agric. 5(1): 53-57

Rahman M. Z., M. H. Rahman, M. E. Haque, M. H. Kabir, S. L. Naher, K. M. K. B. Ferdaus, A. K. M. N. Huda, M. S. Imran and M. Khalekuzzaman. 2006 Banana Based Intercropping System in North-west Part of Bangladesh, J. Agron. 5(2):228231. 
